\title{
ANALISIS NILAI MORAL DALAM NOVEL NEGERI 5 MENARA KARYA AHMAD FUADI DAN PEMANFAATANNYA DALAM PEMBELAJARAN BAHASA INDONESIA DI SMA
}

\author{
Ati Suciawati Dewi ${ }^{1}$, Emah Khuzaemah ${ }^{2}$, Tati Sri Uswati ${ }^{3}$ \\ Institut Agama Islam Negeri Syekh Nurjati Cirebon \\ 1atisuciawatidewi@gmail.com; 2emah_kh@yahoo.co.id; 3tatisriuswati@gmail.com
}

\begin{abstract}
ABSTRAK
Penelitian ini bertujuan untuk menganalisis nilai moral dalam novel Negeri 5 Menara karya Ahmad Fuadi dengan mendeskripsikan kutipan-kutipan nilai moral yang terdapat dalam novel Negeri 5 Menara karya Ahmad Fuadi dan pemanfaatannya dalam pembelajaran bahasa Indonesia di SMA yaitu menyusun rencana pelaksanaan pembelajaran.

Jenis penelitan yang digunakan pada peneliti ini menggunakan kualitatif dengan metode analisis isi. Sumber data yang digunakan dalam penelitian ini adalah novel Negeri 5 Menara karya Ahmad Fuadi. Teknik pengumpulan data dalam penelitian ini dengan menggunakan teknik baca dan teknik catat serta instrumen yang digunakan dalam penelitian ini menggunakan kartu data. Keabsahan data yang digunakan dalam penelitian ini dilakukan dengan meningkatkan ketekunan. Teknik analisis data dalam penelitian ini dilakukan dengan model Miles dan Huberman yang dilaksanakan dengan tiga tahap, yaitu reduksi data, penyajian data, dan penarikan kesimpulan.

Hasil penelitian ini menunjukkan bahwa nilai-nilai moral yang terdapat dalam novel Negeri 5 Menara karya Ahmad Fuadi terdapat tiga jenis nilai moral, Pertama hubungan manusia dengan diri sendiri yaitu jujur, disiplin, rajin, dan tanggung jawab. Kedua, hubungan manusia dengan manusia lain yaitu empati dan rasa hormat. Ketiga, hubungan manusia dengan Tuhan yaitu berdoa dan bersyukur. Berdasarkan dari hasil analisis di atas, dapat dijadikan pemanfaatan untuk menyusun rencana pelaksanaan pembelajaran (RPP) Bahasa Indonesia kelas XII SMA semester genap kurikulum 2013.
\end{abstract}

Kata Kunci: nilai moral, novel, rencana pelaksanaan pembelajaran.

\section{ABSTRACT}

This study aims to analyze the moral values in the novel Negeri 5 Menara by Ahmad Fuadi by describing the quotations of moral values contained in the novel Negeri 5 Menara by Ahmad Fuadi and their use in Indonesian language learning in high school, namely compiling a lesson plan.

The type of research used in this research is qualitative with the content analysis method. The data source used in this study is the novel Negeri 5 Menara by Ahmad Fuadi. Data collection techniques in this study using reading techniques and note taking techniques and instruments used in this study using data cards. The validity of the data used in this study was carried out by increasing persistence. The data analysis technique in this study was carried out with the Miles and Huberman model which was carried out in three stages, namely data reduction, data presentation, and conclusion drawing.

The results of this study indicate that there are three types of moral values contained in the novel Negeri 5 Menara by Ahmad Fuadi. First, human relations with oneself, namely honesty, discipline, diligence, and responsibility. Second, human relations with other humans, namely empathy and respect. Third, the relationship between humans and God is prayer and 
gratitude. Based on the results of the analysis above, it can be used to prepare a lesson plan (RPP) for Indonesian for class XII SMA even semester of the 2013 curriculum.

Keywords: moral values, novel, lesson plan.

\section{PENDAHULUAN}

Karya sastra merupakan sarana untuk menyampaikan pesan kepada penikmatnya. Pembelajaran yang terdapat dalam suatu karya sastra berupa nilai moral, akhlak, dan budi pekerti. Dalam suatu karya sastra nilai moral dapat mencerminkan pandangan hidup seorang pengarang yang hendak disampaikan kepada penikmatnya Nurgiyantoro (2013: 429-430). Damono (dalam Rosyanti, 2017: 182) menjelaskan bahwa diciptakannya karya sastra oleh pengarang atau sastrawan ialah untuk dinikmati, dipahami, dan dapat dimanfaatkan dalam kehidupan.

Novel merupakan sebuah karya fiksi tertulis yang berbentuk naratif dan biasanya dalam bentuk cerita (Nurgiyantoro, 2013: 4). Novel merupakan rangkaian kehidupan sosial pengarang terhadap kenyataan yang ditemukan dalam masyarakat dengan menceritakan kejadian kehidupan seperti peristiwa, norma, dan ajaranajaran agama (Nopianti, 2017: 199).

Karya sastra menjadi sarana untuk mengupkapkan prikiran pengarang dengan menyuguhkan nilai-nilai, nilai-nilai tersebut dapat berupa nilai moral yang dapat dijadikan sebagai pembelajaran kepada penikmatnya sehingga dapat meneladani dan menerapkan perilaku nilai moral yang baik. Sjarkawi (2014: 27) memaparkan bahwa moral berasal dari bahasa Latin ialah kata "mos" yang berarti adat istiadat, kebiasaan, cara tingkah laku, dan kelakuan. Sedangkan mores berarti kelakuan, adat istiadat, cara hidup tabiat, watak, dan akhlak.

Mengenai pengertian moral dalam suatu karya sastra tidak berbeda dengan pengertian moral secara umum, yaitu mengenai nilai baik dan buruk yang diterima secara umum dan berpangkal pada nilai-nilai kemanusiaan. Dalam hal ini, Kenny (dalam Nurgiyantoro, 2013: 430) menjelaskan bahwa moral dalam suatu karya sastra merupakan suatu sarana yang dapat berhubungan dengan ajaran moral tertentu yang bersifat praktis, sehingga dapat diambil dan ditafsirkan lewat cerita yang bersangkutan dengan penikmatnya. Pengarang memberikan berbagai contoh tentang hal-hal yang berhubungan dengan suatu masalah kehidupan melalui cerita, seperti sopan santun, sikap, dan tingkah laku dalam bergaulan. Model yang dapat ditampilkan dalam cerita itu lewat sikap dan tingkah laku para tokoh-tokohnya. Nurgiyantoro (2013: 430) menjelaskan bahwa moral yang terdapat dalam suatu karya sastra bisa dipandang sebagai amanat atau pesan. Dari sikap dan tingkah laku para tokoh dalam cerita, pembaca diharapkan dapat mengambil pelajaran dan pesan-pesan moral yang disampaikan atau di amanatkan oleh pengarang.

Rendahnya nilai moral di kalangan masyarakat khususnya para remaja yang kurang dalam berperilaku baik. Dengan seiringnya perkembangan zaman dan tekonologi informasi yang semakin canggih, pada zaman sekarang ini banyak remaja 
khususnya pelajar yang ikut terbawa arus dalam berperilaku yang tidak baik. Mengingat rendahnya moral masyarakat Indonesia khususnya di kalangan pelajar yang semakin menurun. Dapat dilihat dari contoh kasus tawuran antarpelajar yang sekarang ini kerap terjadi.

Melihat kondisi pendidikan zaman sekarang ini yang jauh dalam beretika dan bertata krama. Rendahnya nilai moral peserta didik khususnya usia remaja (SMA) menjadi poin utama yang perlu dibenahi. Pada zaman sekarang ini, sering melihat perilaku negatif para pelajar seperti tawuran antarpelajar. Perbuatan tawuran tersebut tidak baik karena dapat merugikan diri sendiri dan masyarakat sekitar. Tawuran ini khususnya sering terjadi di daerah Kota Cirebon tepatnya di Jalan By Pass Perjuangan, tawuran antarpelajar SMA ini kerap terjadi ketika sehabis pulang sekolah. Dalam hal ini perlu perhatian yang cukup dari orang tua, guru serta masyarakat sekitar. Hal tersebut perlunya pembenahan moral pada peserta didik, dengan melalui proses pembelajaran di sekolah. Salah satu pembelajaran yang dapat membenahi moral peserta didik adalah pembelajaran mengenai karya sastra.

Dengan menganalisisnya nilai moral karena peneliti melihat kondisi pelajar zaman sekarang ini kurangnya dalam berperilaku seperti tawuran antarpelajar SMA yang kerap tejadi di Jalan By Pass Perjuangan Kota Cirebon, sehingga dalam penelitian ini mengenai nilai moral dapat diajarkan kepada peserta didik dengan cara membaca karya sastra dan menganalisis nilai moral yang terdapat di dalamnya.

Dalam novel negeri 5 menara ini banyak pelajaran positif yang dapat diambil serta pantas untuk diteladani dalam kehidupan sehari-hari dan nilai-nilai tersebut dapat menggugah hati pembaca khususnya peserta didik. Sebuah novel negeri 5 menara dipilih untuk dianalisis karena melihat kondisi pada pendidikan zaman sekarang ini yang jauh dari beretika, bertata krama dan kurangnya berperilaku. Hal ini terbukti dengan adanya fenomena berikut yang bersumber dari radarcirebon.com. Ade (2019: 1) mengatakan tawuran antar pelajar sekolah SMK kembali saling serang di Jalan Perjuangan Kota Cirebon, Rabu (7/8/19) sore. Salah satu diantaranya, tertangkap dan menjadi bulanan siswa lain. Tawuran terjadi saat pulang sekolah atau mendekati Magrib. Salah seorang saksi mata mengatan awal mula terjadinya tawuran, terdapat gerombolan siswa dari arah Jawa Tengah dan turun di Jalan By Pass Brigjen Darsono yang menuju gerombolan pelajar SMK di Jalan Perjuangan berawal saling berpapasan dan kericuhan terjadi mereka saling melempar batu.

Nurgiyantoro (2013: 441-445) menjelaskan bahwa wujud penyampaian moral secara luas dapat dibedakan kedalam beberapa persoalan mengenai jenis dan wujud penyampaian moral ialah sebagai berikut:

Hubungan manusia dengan diri sendiri, dalam persoalan manusia dengan dirinya sendiri dapat bermacam-macam jenis dan tingkatan inetensitasnya. Persoalan tersebut berhubungan dengan rasa percaya diri, harga diri, eksistensi diri, rindu, maut, takut, kesepian, dendam, keterombang-ambingan antara pilihan dan lain-lain yang telah bersifat melihat ke dalam diri seorang individu. 
Hubungan manusia dengan manusia lain (orang lain), dalam kehidupan bermasyarakat manusia sering berhubungan dengan antarsesama manusia lain. Hubungan antarsesama manusia akan mengalami sebuah permasalah. Permasalahan tersebut muncul akibat interaksi antara manusia dengan manusia lain dapat berwujud persahabatan antara lain kokoh atau rapuh, kesetiaan dan pengkhianatan dalam kekeluargaan dapat berwujud hubungan suami-istri, orang tua-anak, dan cinta terhadap suami/istri, anak/orang tua serta pemasalahan lain yang berkaitan dengan interaksi antarmanusia dalam kehidupannya.

Hubungan manusia dengan Tuhan, permasalahan hubungan manusia dengan Tuhan ialah permasalahan yang dialami manusia dalam kehidupan. Permasalahan ini berhubungan dengan aspek ketuhanan misalnya yang berkaitan dengan kataatan. Melalui perilaku menjalankan peritah-Nya dan menjauhi larangan-Nya merupakan ketaatan yang ditunjukkan oleh manusia. Sikap manusiawi yang dimiliki oleh manusia tidak terlepas dari sikap religius. Sikap religius mendasarkan diri untuk patuh kepada Tuhan tanpa memutus tali silaturahmi.

\section{METODE}

Jenis penelitian yang digunakan dalam penelitian ini menggunakan penelitian kualitatif. Kurniawan (2018: 20) menjelaskan bahwa penelitian kualitatif merupakan penelitian yang datanya ialah data kualitatif sehingga analisisnya juga kualitatif (deskriptif) atau penggambaran temuan lapangan yang naturalistik atau apa adanya sesuai kondisi lapangan.

Dalam penelitian ini menggunakan metode analisis isi. Dasar pemikiran pada metode analisis isi ini ialah penafsiran. Ratna (2015: 49) menyatakan bahwa sebagaimana dalam metode kualitatif, dasar pemikiran metode analisis ini ialah penafsiran. Penafsiran pada metode kualitatif akan memberikan perhatian untuk isi pesan. Dalam penelitian ini menggunakan metode analisis isi dengan cara menganalisis isi yang terdapat dalam kutipan-kutipan nilai moral yang terkandung dalam novel Negeri 5 Menara karya Ahmad Fuadi yang sesuai dengan peneliti butuhkan.

Pada penelitian ini sumber data yang digunakan ialah novel Negeri 5 Menara karya Ahmad Fuadi, yang diterbitkan oleh PT Gramedia Pustaka Utama, Jakarta, tahun 2012, dengan tebal 425 halaman, dan 46 bab. Data yang dikaji dalam penelitian ini ialah kutipan-kutipan nilai moral yang terkandung dalam novel Negeri 5 Menara karya Ahmad Fuadi.

Teknik pengumpulan data yang digunakan dalam penelitian ini menggunakan teknik baca dan teknik catat. Teknik baca ialah teknik membaca secara berulangulang dan membaca keseluruhan isi pada novel Negeri 5 Menara yang akan dianalisis dengan tujuan mengetahui permasalahan yang dibutuhkan. Setelah membaca tahap berikutnya mencatat. Teknik catat berguna untuk mengumpulkan data-data berupa kutipan langsung atau kutipan tidak langsung yang terdapat dalam paragraf, kalimat atau dialog yang dianggap penting dan diperlukan oleh peneliti. 
Instrumen yang digunakan dalam penelitian ini menggunakan instrumen kartu data sebagai alat untuk menganalisis nilai-nilai moral pada novel Negeri 5 Menara karya Ahmad Fuadi.

Keabsahan data yang digunakan dalam penelitian ini dilakukan dengan meningkatkan ketekunan. Sugiyono (2016: 272) menjelaskan bahwa meningkatkan ketekunan ialah melakukan pengecekan atau pengamatan dengan cermat dan berkesinambungan. Meningkatkan ketekunan ialah peneliti mengecek data kembali dengan membaca ulang novel Negeri 5 Menara dengan melihat teori-teori yang digunakan dalam penelitian. Setelah peneliti membaca kemudian mengecek data apakah data sudah terkumpul semua dan data tersebut sudah benar atau tidak sesuai dengan peneliti butuhkan.Kemudian jika masih ada data yang belum terkumpul maka peneliti mencatat ulang data yang sesuai peneliti butuhkan.

Dalam penelitian ini, teknik analisis data menggunakan model Miles dan Huberman dengan melalui tiga tahap yaitu reduksi data, penyajian data, dan penarikan kesimpulan. Miles dan Huberman (dalam Sugiyono, 2016: 246) menjelaskan bahwa suatu aktivitas dalam analisis data kualitatif dapat dilakukan secara interaktif dan langsung terus-menerus sehingga datanya jenuh. Sebelum masuk ke langkah-langkah reduksi, dilakukan kegiatan pengumpulan data. Langkahlangkah analisis data ialah sebagai berikut.

Pertama, tahap reduksi data dalam penelitian ini memilih menganalisis nilainilai moral yang terdapat dalam novel Negeri 5 Menara karya Ahmad Fuadi. Adapun tahapan yang dilakukan dalam proses reduksi data dalam penelitian ini yaitu memilih sesuai dengan kategori nilai-nilai moral yang terkandung dalam novel Negeri 5 Menara karya Ahmad Fuadi, meringkas data yang sudah dipilih sesuai dengan peneliti butuhkan, mencatat data yang penting supaya dapat tersimpan dengan baik, dan mengumpulkan data dengan benar supaya proses penelitian dapat berjalan sesuai yang diharapkan.

Kedua, setelah proses reduksi data dalam penelitian ini tahap selanjutnya yaitu penyajian data. Setelah data sudah dipilih maka selanjutnya adalah menyajikan data dalam bentuk deskriptif untuk memudahkan peneliti dalam menafsirkan data yang diperoleh.

Ketiga, penarikan Kesimpulan dalam penelitian kualitatif dapat menjawab pada rumusan masalah yang dirumuskan sejak awal, tetapi mungkin juga tidak. Pada tahap ini dapat ditarik kesimpulan dari hasil reduksi data dengan penyajian data (pengolahan data) mengenai bentuk nilai-nilai moral yang terdapat dalam novel Negeri 5 Menara karya Ahmad Fuadi. Penarikan kesimpulan data hasil analisis ini menjawab rumusan masalah yang pertama yaitu bagaimana bentuk nilai-nilai moral yang terkandung dalam novel Negeri 5 Menara karya Ahmad Fuadi. 


\section{HASIL DAN PEMBAHASAN}

Hasil dan pembahasan dalam novel Negeri 5 Menara karya Ahmad Fuadi terdapat tiga jenis dan wujud penyampaian nilai moral serta pemanfaatannya dalam menyusun rencana pelaksanaan pembelajaran (RPP) ialah sebagai berikut.

A. Nilai Moral

1. Hubungan manusia dengan diri sendiri

Nilai moral hubungan manusia dengan diri sendiri yang terdapat dalam novel Negeri 5 Menara karya Ahmad Fuadi ialah sebagai berikut.

a) Jujur

Jujur merupakan perilaku dengan menjadikan diri sendiri sebagai orang yang dapat dipercaya dalam perkataan, tindakan dan pekerjaan (Samani \& Hariyanto, 2013: 49).

"Tapi Amak, ambo tidak berbakat dengan ilmu agama, ambo ingin menjadi insinyur dan ahli ekonomi," tangkisku sengit. Mukaku merah dan mata terasa panas. (Fuadi, 2012: 9)

Alif merupakan tokoh dalam novel yang digambarkan dengan sikap jujur kepada orang tuanya tentang bakat yang ia miliki. Dari kutipan di atas, terlihat bahwa Alif berkata jujur kepada Amaknya bahwa ia tidak berbakat dengan ilmu agama karena ia ingin menjadi insinyur dan ahli ekonomi. Sikap jujur ditunjukan melalui perilaku berani menyampaikan kebenaran dengan berbicara kepada Amaknya yang sebenarnya bahwa Alif tidak berbakat dengan ilmu agama.

b) Disiplin

Disiplin ialah patuh terhadap tata tertib yang berlaku. Orang yang disiplin akan senantiasa mematuhi setiap peraturan yang berlaku dimanapun dan kapanpun (Samani \& Hariyanto, 2013: 49).

"Kami? Dalam perizinan tidak ada yang mewakili. Kamu minta izin untuk dirimu sendiri." (Fuadi, 2012: 125)

Guru di Pondok Madani sudah terbiasa hidup dengan peraturan. Dari kutipan di atas, terlihat bahwa guru di Pondok Madani sangat disiplin dalam mematuhi peraturan yang telah ditetapkan, memberikan izin kepada muridnya dengan peraturan yang telah ditetapkan. Ustad Torik memberitahu kepada muridnya yang ingin pergi ke luar Pondok harus meminta izin dengan dirinya sendiri tidak boleh ada yang mewakili karena di Pondok Madani semua murid harus mematuhi peraturan dan jika melanggar peraturan akan mendapatkan sanksi.

c) Rajin

Rajin ialah suatu sikap dan perilaku tekun dalam mengerjakan suatu hal baik dan bermanfaat untuk diri sendiri dan orang lain. Sikap rajin yang dimiliki oleh seseorang menumbuhkan disiplin diri (Samani \& Hariyanto, 2013: 49). 
"Dengan semangat tinggi aku selalu mengikuti Ustad Jamil yang dengan ringan mengelok-ngelokkan qalam-nya membuat lekukanlekukan indah kalimat Arab." (Fuadi, 2012: 114)

Alif merupakan tokoh dalam novel yang digambarkan dengan sikap rajin. Dari kutipan di atas, terlihat bahwa Alif orang yang rajin dan tekun dalam mengerjakan suatu hal yang baik dan bermanfaat untuk diri sendiri dan orang lain. Dengan semangat yang tinggi Alif selalu mengikuti Ustad Jamil yang sedang mengelok-ngelokkan qalam-nya untuk membuat lekukan-lekukan kalimat Arab yang sangat indah. Sikap rajin yang dimiliki oleh Alif menumbuhkan disiplin diri yaitu tekun dalam membuat kaligrafi dengan lekukan-lekukan kalimat Arab yang indah.

d) Tanggung Jawab

Tanggung jawab ialah perilaku dan sikap seseorang dalam menjalankan tugas dan kewajibannya terhadap diri sendiri, masyarakat, dan negara (Samani \& Hariyanto, 2013: 49).

"Takut dengan potensi hukuman ini, dengan susah payah aku berhasil menyelesaikan naskahku, setelah berkorban harus pakai baju yang sama dua hari beturut-turut karena tidak sempat mencuci dan sekali melewatkan mandi pagi." (Fuadi, 2012: 150)

Alif merupakan tokoh dalam novel yang digambarkan dengan sikap tanggung jawab. Dari kutipan di atas, terlihat bahwa Alif orang yang tanggung jawab dalam menjalankan tugas dalam menyelesaikan naskah pidato untuk syarat berpidato yang diwajibkan oleh PM. Setelah selesai, kemudian Alif menyerahkan naskah tersebut kepada Kak Jamal. Sebagai bentuk tanggung jawab murid di PM Alif mematuhi peraturan untuk mengikuti pidato dan sebelum berpidato peserta harus menyetorkan naskahnya terlebih dahulu sebelum acara di mulai, dengan tanggung jawab Alif berhasil menyelesaikan naskahnya sampai ia lupa baju yang ia pakai belum sempat di cuci dan Alif melewatkan mandi pagi.

2. Hubungan manusia dengan manusia lain (orang lain)

Nilai moral hubungan manusia dengan manusia lain yang terdapat dalam novel Negeri 5 Menara karya Ahmad Fuadi ialah sebagai berikut.

a) Empati

Empati ialah memahami dan merasakan kehawatiran orang lain (Zubaedi, 2012: 57).

"Tapi aku bisa menjamin makan dan tinggal kalian nanti gratis selama di Bandung. Pergi ke Bandung jelas tidak bayar karena naik mobil bapakku." (Fuadi, 2012: 217)

Atang merupakan tokoh dalam novel yang digambarkan dengan sikap empati kepada kawannya sendiri. Dari kutipan di atas, terlihat 
bahwa Atang memahami dan ikut merasakan kekhawatiran apa yang sedang dialami kawannya sendiri yaitu Alif dan Baso. Sikap empati dapat ditunjukan dengan peduli dan menolong Alif dan Baso yang tidak bisa liburan untuk pulang ke rumahnya. Dengan kepeduliannya Atang mengajak Alif dan Baso untuk ikut pulang ke rumahnya yaitu ke Bandung dan Atang akan menjamin makan dan tinggalnya Alif dan Baso dengan gratis selama di Bandung.

b) Rasa Hormat

Rasa hormat ialah menghargai orang lain dengan berlaku baik dan sopan (Zubaedi, 2012: 61).

"Aku cium tangan beliau dan duduk disampingnya, agak lesu. Ayah hanya tertawa tanpa bunyi dan berkata, "Di kampung lagi musim durian"." (Fuadi, 2012: 373)

Alif merupakan tokoh dalam novel yang digambarkan dengan sikap hormat. Dari kutipan di atas, terlihat bahwa Alif orang yang hormat mengahargai orang lain dengan berlaku baik dan sopan kepada orang tua yaitu kepada Ayahnya. Rasa hormat ditunjukkan dengan cara mencium tangan dan duduk disamping Ayahnya. Alif berlaku baik dan sopan kepada Ayahnya yang baru saja datang dari kampungnya untuk menengok anaknya yaitu Alif, dengan sopan Alif mencium tangan Ayahnya yang baru datang dan duduk disampingnya.

3. Hubungan manusia dengan Tuhan

Nilai moral hubungan manusia dengan Tuhan yang terdapat dalam novel Negeri 5 Menara karya Ahmad Fuadi ialah sebagai berikut.

a) Berdoa

Berdoa merupakan salah satu sarana untuk berkomunikasi antara hamba dengan Allah SWT dalam keadaan tertentu, untuk meminta dan memohon pertolongan serta beribadah kepada Allah SWT (Mursalim, 2011: 63).

"Maka setelah shalat Ashar berjamaah, aku terpekur lebih lama memanjatkan doa sebagai seorang jasus yang "teraniaya" karena belum menemukan pelangar aturan. Aku dengan khusyuk memohon Allah memudahkan misi ini sehingga kehidupanku kembali tenang dan damai." (Fuadi, 2012: 82)

Alif merupakan tokoh dalam novel yang digambarkan dengan sikap selalu berdoa kepada Allah SWT. Dari kutipan di atas, terlihat bahwa Alif selalu berdoa kepada Allah SWT untuk meminta pertolongan kepada Allah. Setelah shalat Ashar berjamaah, Alif memanjatkan doa memohon untuk dimudahkan bahwa dirinya sebagai seorang jasus agar dimudahkan dalam menemukan orang yang melanggar aturan. Dengan khusyuk Alif memohon pertolongan kepada Allah untuk dimudahkan 
dalam mencari orang yang melanggar aturan dan memohon agar kehidupannya kembali tenang dan damai.

b) Bersyukur

Syukur ialah salah satu dari kajian psikologi positif yang berarti mengucapkan terima kasih atas anugerah yang diberikan oleh Allah kepada umatnya. Syukur menjadi bagian dari ajaran agama Islam, yang sering dipraktikan dalam kehidupan sehari-hari, dengan pengucapan "Alhamdulillah" sebagai simbol dari rasa kebersyukuran (Akmal \& Masyhuri, 2018: 2-3)

"Alhamdulillah, terima kasih Tuhan. Setelah semua proses menegangkan ini, aku ternyata malah diberi kepercayaan besar." (Fuadi, 2012: 316)

Alif merupakan tokoh dalam novel yang digambarkan dengan sikap bersyukur kepada Allah SWT. Dari kutipan di atas, terlihat bahwa Alif mengucapkan terima kasih kepada Allah SWT yang telah memberikan Alif kepercayaan untuk menjadi Student Speaker artinya murid yang berpidato menyambut tamu penting, setelah Ustad Torik memberikan ketegangan dan alhamdulillah Alif diberi kepercayaan untuk menyambut tamu penting dari luar negeri.

\section{B. Pemanfaatan Rencana Pelaksanaan Pembelajaran}

Pemanfaatan dalam penelitian ini ialah menyusun rencana pelaksanaan pembelajaran (RPP) pelajaran bahasa Indonesia SMA kelas XII semester genap pada kompetensi dasar (KD) 3.9 menganalisis isi dan kebahasaan novel dan 4.9 merancang novel atau novelet dengan memperhatikan isi dan kebahasaan baik seacra lisan maupun tertulis kurikulum 2013, berdasarkan hasil dari analisis nilai moral Negeri 5 Menara karya Ahmad Fuadi. Rancangan pelaksanaan pembelajaran pada penelitian ini merancang dengan pembuatan rencana pelaksanaan pembelajaran dengan memerhatikan aturan dari silabus kurikulum 2013 yang telah ditetapkan. Dalam penelitian ini Pertama, memilih kompetensi dasar (KD) dari silabus kurikulum 2013 yang sesusai dengan penelitian. Kedua, membuat rancangan untuk pembuatan RPP yang sesuai dengan kompetensi dasar (KD) dan hasil dari penelitian. Ketiga, membuat rencana pelaksanaan pembelajaran sesuai dengan aturan kurikulum 2013 yang ditetapkan.

\section{SIMPULAN}

Berdasarkan hasil penelitian dalam novel Negeri 5 Menara karya Ahmad Fuadi. Terdapat tiga jenis nilai moral pertama, nilai moral yang berhubungan dengan diri sendiri yaitu jujur, disiplin, rajin, dan tanggung jawab. Kedua, nilai moral yang berhubungan dengan manusia lain yaitu empati dan rasa hormat. Ketiga, nilai moral yang berhubungan dengan Tuhan yaitu berdoa dan bersyukur. Pada penelitian ini akan dimanfaatkan untuk pembuatan rencana pelaksanaan pembelajaran (RPP) berdasarkan hasil analisis nilai-nilai moral yang terdapat dalam 
novel Negeri 5 Menara karya Ahmad Fuadi. Manfaat dalam penelitian ini diharapkan dapat menambah pengetahuan dan wawasan siswa dan siswi SMA. Peneliti selanjutnya agar mengkaji nilai moral yang lebih bertambah lagi dan hasil analisis tersebut dapat dibuat rencana pelaksanaan pembelajaran (RPP) yang dapat diterapakan di sekolah.

\section{DAFTAR PUSTAKA}

Ade. (2019). Terjebak Tawuran, Seorang Pelajar Menjadi Bulan-Bulanan. Retrieved December 19, 2019, from www.radarcirebon.com 8 Agustus 2019 website: https://www.radarcirebon.com/2019/08/08/terjebak-tawuran-seorangpelajar-menjadi-bulan-bulanan/

Akmal, \& Masyhuri. (2018). Konsep Syukur (Gratefulnes) (kajian Empiris Makna Syukur bagi Guru Pon.Pes Daarunnahdhah Thawalib Bangkinang Seberang, Kampar, Riau). Jurnal Komunikasi Dan Pendidikan Islam, 7(2), 1-22. Retrieved from journal.staimsyk.ac.id/index.php/almanar/article/download/86/84

Fuadi, A. (2012). Negeri 5 Menara. Jakarta: PT Gramedia Pustaka Utama.

Kurniawan, A. (2018). Teori dan Praktik Penelitian Tindakan Kelas. Cirebon: Eduvision.

Mursalim. (2011). Doa dalam Perspektif Al-Quran. Jurnal Al-Ulum, 11(1), 63-78. Retrieved from journal.iaingorontalo.ac.id/index.pph/au/article/view/65

Nopianti, S. D. (2017). Nilai Moral Dalam Novel Daun Yang Jatuh Tak Pernah Membenci Angin Karya Tere Liye. Jurnal Diksatrasia, 1(2), 199-202. Retrieved from http://jurnal.unigal.ac.id/index.php/diksatrasia/article/download/599/497

Nurgiyantoro, B. (2013). Teori Pengkajian Fiksi. Yogyakarta: Gadjah Mada University Press.

Ratna, N. K. (2015). Teori, Metode dan Teknik Penelitian Sastra. Yogyakarta: Pustaka Pelajar.

Rosyanti, S. (2017). Nilai Moral Dalam Novel Surat Kecil untuk Tuhan Karya Agnes Davonar. Jurnal Diksatrasia, 1(2), 182-190. Retrieved from jurnal.unigal.ac.id/index.php/diksatrasia/aticle/view/597

Samani, M., \& Hariyanto. (2013). Konsep dan Model Pendidikan Karakter. Bandung: Remaja Rosdakarya.

Sjarkawi. (2014). Pembentukan Kepribadian Anak. Jakarta: Bumi Aksara.

Sugiyono. (2016). Metodologi Penelitian Kuantitatif, Kualitatif dan R\&D. Bandung: Alfabeta.

Zubaedi. (2012). Desain Pendidikan Karakter. Jakarta: Kencana Prenada Media Grup. 